\title{
АПАРАТ ОЦІНКИ КУКСИ ДЛЯ ПРОТЕЗУВАННЯ КІНЦІВОК
}

\author{
๑І. Ю. Худецький ${ }^{1,2}$, Ю. В. Антонова-Рафі ${ }^{2}$, Н. М. Худецька ${ }^{3}$, І. В. Пущина ${ }^{4}$ \\ Інститут електрозварювання імені $Є$. О. Патона Національної академії наук України, м. Київ ${ }^{1}$ \\ Національний технічний університет України «КПІ імені І. Сікорського», м. Київ ${ }^{2}$ \\ Перший медичний коледж, м. Київ \\ Запорізький національний технічний університет 4
}

РЕЗЮМЕ. Розроблено та випробувано необхідні зонди, які поєднують в собі здатність визначати форму та стан тканини кукси. Зонди мають шкалу регулювання відносно «нульового» рівня кукси та об' єднані з датчиками руху. На основі отриманих даних програмне забезпечення формує форму протеза. Це дає можливість здійснювати автоматичні вимірювання, забезпечує метрологічні вимоги під час калібрування пристрою. Для визначення механічних властивостей тканин зонди оснащені датчиками тиску та пристроями для створення конкретного механічного навантаження на зонди, що відповідає реальному навантаженню на куксу в цілому. $€$ кілька режимів для вимірювання механічних властивостей тканини кукси.

Метою дослідження було розробити прилад для визначення 3-D форми та механічних характеристик тканин кукси, що взаємодіють з гільзою протеза.

Матеріал і методи. В процесі дослідження були проаналізовані матеріали про основні найпоширеніші технології протезування кінцівок, медичні, реабілітаційні та ерготерапевтичні проблеми пацієнтів в процесі протезування і експлуатації протезів. Для проектування були використані пакети MatCad, SolidWorks та технології метрологічної оцінки датчиків.

Визначено також вимоги до автоматизації втрати даних та сумісності з технологіями CAD-CAM. У конструкції пристрою враховуються економічні та технологічні можливості його реалізації. Технологія може бути частиною технології CAD/CAМ для виробництва протезів кінцівок.

Висновки. Створений пристрій дозволяє розробляти форму та стан залишкової кінцівки тканини. Автоматизована система дозволяє знімати та збирати дані з вимірювальних зондів і передавати ці дані на комп'ютер для подальшого аналізу. Це дозволяє використовувати розроблений пристрій як CAD/CAM технологічний елемент при формуванні оптимальної протезної системи «протезування кінцівок».

КЛючовІ СЛОВА: протезування; протезування кінцівок; технологія CAD/CAM; рукавний протез; кукса ампутованої кінцівки.

Вступ. Термін «ампутація» означає відсічення кінцівки на протязі кістки з метою видалення її нежиттєздатної частини. Аналогічним оперативним втручанням за своїм значенням $\epsilon$ і екзартикуляція, однак при такій операції видалення нежиттєздатної кінцівки проводиться по лінії суглоба. Ампутація або екзартикуляція передбачає видалення частини або всієї пошкодженої кінцівки заради врятування життя хворого.

Тому надзивичайно важливо надати людині, яка пройшла через операцію ампутації, якомога найкращі умови для подальшого життя та праці, оскільки це полегшить страждання та збільшить шанси на швидшу адаптацію до нових умов життя після ампутації.

Більшість сучасних технологій при формуванні «гільзи» протеза враховують тільки форму кукси, не визначаючи стан їі тканин, що $€$ недостатнім для вирішення проблеми протезування.

Травми та поранення, які призводять до втрати кінцівок, $\epsilon$ поширеним явищем сьогодення. За статистикою ВООЗ, понад 600 мільйонів людей у світі $\epsilon$ інвалідами, що втратили кінцівки. Історія і практика протезування кінцівок $\epsilon$ віддзеркаленням історії медицини як такої. Разом з тим, цілий ряд проблем у протезуванні не вирішені до цього дня. Кожна ампутація та утворена кукса $\epsilon$ унікальною. Протез, який дозволяє у певній мірі компенсувати втрачені функції, умовно можна поділити на дві складові. Одна це більш чи менш типова функціональна частина. Друга, це персоніфікована частина протеза, так звана «гільза», яка поєднує функціональну частину протеза та куксу кінцівки пацієнта. Формування якісної «гільзи» протеза, яка у повній мірі відповідає стану кукси, у значній мірі визначає ефективність застосування протеза. Умовою оптимальної гільзи $\epsilon$ відповідність гільзи формі та стану тканин кукси. Більшість сучасних технологій при формуванні «гільзи» протеза враховують тільки форму кукси. Сучасні методи не дозволяють ефективно аналізувати стан кукси, оскільки не дають змоги отримати характеристики тканин кінцівки. Дані, отримані такими способами, базуються лише на геометричних параметрах, що не забезпечує можливості конструювання комфортного для пацієнта протеза. Метою роботи $\epsilon$ проектування приладу для зняття параметрів форми та стану тканин кукси.

Метою дослідження була розробка приладу для визначення 3-D форми та механічних харак- 
Огляди літератури, оригінальні дослідження, погляд на проблему

теристик тканин кукси, що взаємодіють з гільзою протеза.

Матеріал і методи. В процесі дослідження були проаналізовані матеріали про основні найпоширеніші технології протезування кінцівок, медичні, реабілітаційні та ерготерапевтичні проблеми пацієнтів в процесі протезування і експлуатації протезів. Для проектування були використані пакети MatCad, SolidWorks та технології метрологічної оцінки датчиків.

Результати й обговорення. Авторами проведений аналіз сучасних методів зняття показань $з$ кукси.

На сьогодні найпоширенішим способом є побудова кукси приймача методом гіпсового зліпка (рис. 1)

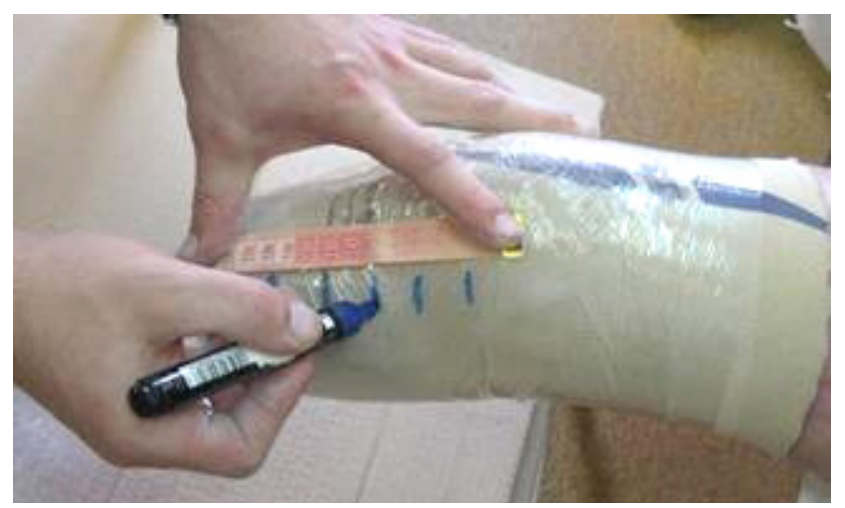
зліпка.

Рис. 1. Побудова кукси приймача методом гіпсового

Метод оптичного зняття нерівностей. Цей метод передбачає фото- та відеозйомку ампутованної частини тіла. Перевагою методу є швидкість та простота виконання процедури. Недоліком $\epsilon$ неможливість отримання даних про тканини.

Метод зняття характеристик рентгеном. Метод надає можливість отримати дані про місцезнаходження та глибину кістки в ампутованій кінцівці. Це дозволяє моделювати куксоприймач з урахуванням місцезнаходження кістки. Недолік полягає в неможливості отримання характеристик м' яких тканин.

Авторами запропонований метод послідовного зняття даних. Метод базується на знятті нерівностей кукси та отриманні характеристик м'яких та твердих тканин шляхом використання матриці аналізуючих рейок, які спроектовані таким чином, щоб без опору отримувати значення нерівностей кукси, та з опором вимірювати жорсткість поверхні кукси.

Авторами побудована блок-схема і на базі отриманих даних побудовані електрична схема та креслення приладу.

Після постановки необхідних задач до приладу було вирішено використовувати два види дат- чиків для зняття характеристик з кукси, а саме п'єзоелемент і резистор, зі зміною опору цих датчиків і після обробки даних значень через апаратну частину приладу отримуватимемо необхідні дані, які при зіставленні дадуть необхідну характеристику кукси.

Отримані результати були зіставлені, до них належать:

- Дані та параметри, які необхідно отримувати у ході роботи приладу.

- Геометричні розміри кукс, які будуть вимірюватись.

- Необхідні геометричні розміри апаратної частини приладу.

На базі цих даних було побудовано складальне креслення та надано креслення рейкового датчика для зняття показань з кукси.

Двоетапний датчик забезпечує достовірність результатів за рахунок своєї конструкції, а саме.

Перший етап - це зняття геометричних розмірів кукси, що фіксується резистором, та надання форми датчиків для другого етапу вимірювання.

Другий етап - це отримання характеристики м'яких та твердих тканин кукси під впливом прикладених до неї зусиль, що фіксується п'єзоелементом, розташованим на місці контакту датчика 3 куксою.

Малі габарити приладу та його можливість працювати тільки при підключенні до комп'ютера дозволяють його транспортувати за необхідності.

Отримані дані дадуть необхідні параметри для моделювання та конструювання комфортного та ефективного протеза. А саме, на місці м' яких тканин, при моделюванні, буде враховано та використано жорсткі матеріали, які будуть жорстко контактувати з куксою та міцно утримуватимуть куксу в куксоприймачі. На місці твердих тканин знаходитиметься м'яка підкладка для зменшення тертя на цю ділянку і уникнення дискомфорту та натирань при користуванні протезом.

Авторами запропонований метод, що не схожий на стандартизовані методи. Він дозволяє отримати характеристики нерівності кукси, а також значення характеристик м'яких та твердих тканин кінцівки, що в подальшому дозволить змоделювати та спроектувати куксоприймач 3 формою, яка дає змогу комфортно та надійно утримувати протез на куксі.

Прилад повинен мати систему, яка дозволить без тиску, тобто без суттєвої ваги вимірювати нерівності кукси, ці дані будуть заноситись в комп 'ютер у вигляді матриці даних, що формуватимуть об'ємний графік.

Після отримання даних нерівностей необхідно надати тиск при попередньо збереженій формі минулого вимірювання, це надасть максимальної 
Огляди літератури, оригінальні дослідження, погляд на проблему

достовірності виміру тиску. Дані тиску у вигляді матриці формуватимуться на комп'ютері, і так само формуватимуть об'ємний графік.

Для забезпечення правильності та надійності отримання даних з датчиків потрібно забезпечи- ти схему реле, яке буде перемикати датчики при команді з блоку керування. Також це зменшить необхідну кількість датчиків напруги.

Кінцева блок-схема приладу для отримання характеристик кукси зображена на рисунку 2.

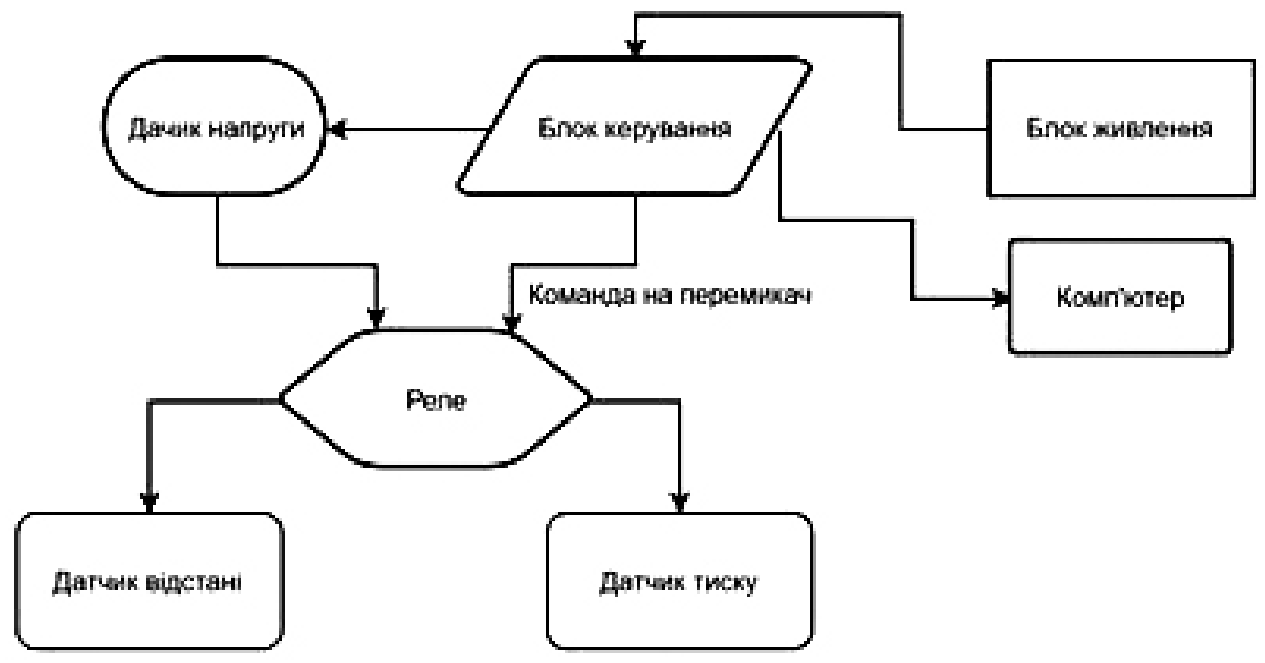

Рис. 2. Блок-схема приладу для визначення нерівностей поверхні та розподілу тиску при навантаженні на куксу.

Команда на перемикання реле буде здійснюватись через комп'ютер.

Технологічні характеристики приладу

Прилад функціонує за принципом власної ваги, тобто датчики під власною вагою займають крайнє нижнє положення.

Прилад складається з 3 основних частин: куксоприймача, блоку рейкових датчиків, блоку електроніки. Основним компонентом приладу $\epsilon$ вимірювальна рейка, їі конструкція дозволяє поетапно вимірювати без навантаженя амплітуду на куксі, а на наступному етапі вимірювати реакцію поверхні кукси на тиск.

На рисунку 3 зображено креслення з поясненнями елементів рейки.

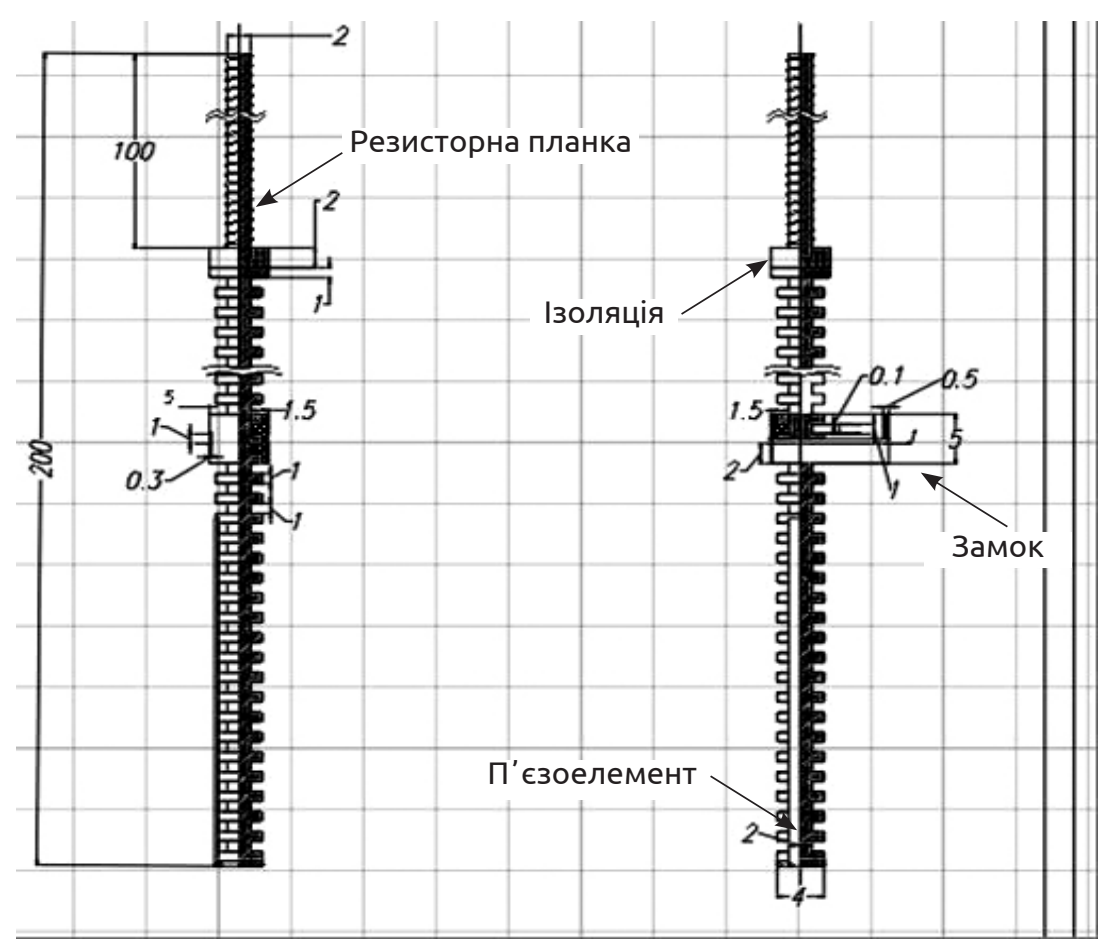

Рис. 3. Вимірювальна рейка. 
Огляди літератури, оригінальні дослідження, погляд на проблему

Для визначення форми кукси запропоновано використання вимірювальної частини апарату, діаметр корпусу якого на 20 мм перевищує максимальний діаметр кукси в зоні гільзи протеза. У ній розміщена матриця рухомих вимірювальних зондів.

Це забезпечує можливість проводити автоматизовані вимірювання, забезпечує метрологічні вимоги при градуюванні та повірці приладу.

Для визначення механічних характеристик тканин зонди обладнані датчиками тиску та пристосуванням для створення питомого механічного навантаження на зонди, яке відповідає реальному навантаженню на куксу загалом.

Висновки. Розроблений апарат дозволяє визначати форму та стан тканин кукси. До його складу входить автоматизована система зняття, накопичення даних з вимірювальних зондів 3 можливістю передачі цих даних на ЕВМ для подальшого аналізу. Це дозволяє використовувати розроблений апарат як елемент CAD/CAM технології при формуванні оптимальної гільзи протеза кінцівок. Даний прилад надає змогу легко, швидко та ефективно отримувати значення 3 кукси, необхідні для подальшого моделювання, проектування та конструювання куксоприймачів для протезів, що забезпечить високу ефективність обслуговування інвалідів з втраченими кінцівками, також підвищить комфорт від використання протеза, змодельованого за допомогою цього приладу.

\section{ЛІТЕРАТУРА}

1. Ампутації та екзартикуляції на кінцівках [Електронний ресурс]. - 2013. - Режим доступу до ресурсу: http://intranet.tdmu.edu.ua/data/kafedra/ internal/xirtop/ classes_stud/uk/med/lik/ntn/

2. Аналіз методів попереднього оброблення біомедичних зображень / С. В. Павлов, Д. В. Вовкотруб, С. О. Романюк [та ін.] // 1. - 2015. - С. 18-23

3. Батько Ю. М. Метод точкового аналізу даних $з$ площини / Ю. М. Батько, О. М. Березький, Г. М. Мельник / Матеріали 4-ї Міжнародної науково-технічної кон-

ференції : Комп'ютерні науки та інформаційні технології 2009, (15 - 17 жовтня, 2009, Львів, Україна). - Львів, 2012. - C. 48-51.

4. The device for assessments configuration and condition of the amputation stump of a human limb for prosthetics / Proceedings of the International Scientific Conference "International Trends in Science and Technology" / I. Yu. Khudetskyy, Ju. V. Antonova-Rafi, N. M. Khudetskaya, H. V. Melnyk (Warsaw, Poland) Dolna 17 October 2017. P.15-17.

\section{REFERENCES}

1. Amputatsii ta ekzartikuliatsii na kintsivkakh [Amputation and exarcticulation on the limbs] (2013). base.garant.ru. Retrieved from: http://intranet.tdmu.edu.ua/data/ kafedra/internal/xirtop/classes_stud / uk / med / lik / ntn / [in Ukrainian].

2. Pavlov, S.V., Vovkotrub, D.V., \& Romaniuk, S.O. (2015). Analiz metodiv poperednoho obroblennia biomedychnykh zobrazhen [Analysis of methods for preliminary processing of biomedical images]. 1, 18-23 [in Ukrainian].

3. Batko, Yu.M., Berezkyi, O.M., Melnyk, H.M. (2012). Metod tochkovoho analizu danykh z ploshchyny [Method of point analysis of data from the plane]. Materialy 4-i

Mizhnarodnoi naukovo-tekhnichnoi konferentsii: Kompiuterni nauky ta informatsiini tekhnolohii 2009 - Materials of the 4th International Scientific and Technical Conference: Computer Science and Information Technologies 2009, 48-51 [in Ukrainian].

4. Khudetskyy, I.Yu., Antonova-Rafi, Ju.V., Khudetskaya, N.M., \& Melnyk, H.V. (2017). The device for assessments configuration and condition of the amputation stump of a human limb for prosthetics. Proceedings of the International Scientific Conference "International Trends in Science and Technology", 15-17.

\section{АППАРАТ ОЦЕНКИ КУЛЬТИ ДЛЯ ПРОТЕЗИРОВАНИЯ КОНЕЧНОСТЕЙ ФИ. Ю. Худецкий ${ }^{1,2}$, Ю. В. Антонова-Рафи², Н. М. Худецкий, И. В. Пущина \\ Институт электросварки имени Е. О. Патона Национальной академии наук Украины' ${ }^{1}$ г. Киев Национальный технический университет Украины «КПИ имени И. Сикорского»², г. Киев \\ Первый медицинский колледжз, г. Киев \\ Запорожский национальный технический университет ${ }^{4}$}

РЕЗЮМЕ. Разработаны дизайн и тестирование необходимых зондов, которые сочетают в себе способность определять форму и состояние ткани культи. Зонды имеют шкалу управления относительно «нулевого» уровня культи и объединены с датчиками движения. На основе полученных данных программное обеспечение формирует форму протеза. Это дает возможность проводить автоматические измерения, обеспечивает метрологические требования при калибровкеустройства. Для определения механических свойств тканей зонды оснащены датчиками 
Огляди літератури, оригінальні дослідження, погляд на проблему

давления и устройствами для создания определенной механической нагрузки на датчики, что соответствует реальной нагрузке на культю в целом. Существует несколько способов измерения механических свойств культи ткани.

Целью исследования было разработать прибор для определения 3-D формы и механических характеристик тканей культи, взаимодействующих с гильзой протеза.

Материал и методы. В процессе исследования были проанализированы материалы об основных наиболее распространенных технологиях протезирования конечностей, медицинские, реабилитационные и ерготерапевтические проблемы пациентов в процессе протезирования и эксплуатации протезов. Для проектирования были использованы пакеты MatCad, SolidWorks и технологии метрологической оценки датчиков.

Также были определены требования к автоматизации потери данных и совместимости с технологиями СAD/ САМ. Конструкция устройства учитывает экономические и технологические возможности его реализации. Технология может быть частью технологии CAD/CAM для производства протезов конечностей.

Выводы. Разработанное устройство позволяет рассчитывать форму и состояние окончательной ткани конечности. Автоматизированная система позволяет снимать и собирать данные с измерительных зондов и передавать эти данные на компьютер для дальнейшего анализа. Это позволяет использовать разработанное устройство в качестве элемента технологии CAD/CAM при формировании оптимальной и простой оболочки протеза конечности.

КЛЮЧЕВЫЕ СЛОВА: протезирование; протез конечности; технология CAD/CAM; протезирование рукавов; культя ампутированной конечности.

\section{THE DEVICE FOR RESIDUAL STUMP ASSESSMENT AT LIMB PROSTHETICS OI. Yu. Khudetskyy',2, Ju. V. Antonova-Rafi' ${ }^{2}$ N. M. Khudetska ${ }^{3}$, I. V. Pushchyna ${ }^{4}$ \\ Ye. Paton Institute of Electric Welding of the National Academy of Sciences of Ukraine ${ }^{1}$, Kyiv National Technical University of Ukraine «I. Sikorsky Kyiv Polytechnic Institute»², Kyiv First Medical College $e^{3}$ Kyiv Zaporizhzhia National Technical University ${ }^{4}$}

SUMMARY. The design and testing of the necessary probes, which combine the ability to determine the shape and condition of the tissue of the stump, are developed. The probes have a control scale relative to the "zero" level of the stump and combined with the motion sensors. On the basis of the data obtained, the software forms a shape of the box. It provides an opportunity to carry out automated measurements, provides metrological requirements during calibration and calibration of the device. To determine the mechanical properties of fabrics, probes are equipped with pressure sensors and devices to create a specific mechanical load on the probes, which corresponds to the real load on the stump as a whole. There are several modes for measuring the mechanical properties of tissue stump.

The aim of the study - to develop a device for determining the 3-D shape and mechanical characteristics of tissues of the coil interacting with the prosthetic sleeve.

Material and Methods. In the course of the study, materials about the most common prosthetic technologies of the limbs, medical, rehabilitation and ergotherapeutic problems of patients in the process of prosthetics and maintenance of prosthetics were analyzed. For design, MatCad, SolidWorks and metrology sensor technology were used.

Requirements for automation of data loss and compatibility with CAD-CAM technologies were also specified. The design of the device takes into account the economic and technological capabilities of its implementation. Technology can be part of CAD / CAM technology for the manufacture of limb prostheses.

Conclusion. Developed device allows the developing the shape and the state of residual limb tissues. Automated system allows take off and data collection from measure probes and transmits these data to computer for further analysis. This allows using the developed device as CAD-CAM technology element at formation of optimal - prosthetic socket of limb prosthetic.

KEY WORDS: prosthetics; limb prosthesis; CAD/CAM technology; sleeve prosthesis; stump of amputated limb.

Отримано 07.09.2017 